\section{Nauplius}

The Journal OF The Brazilian Crustacean Society

\title{
Prohibiting pet crayfish does not consistently reduce their availability online
}

Zen Faulkes' (D) orcid.org/0000-0003-4049-7034

1 ESCNE 2.364, Department of Biology, The University of Texas Rio Grande Valley, Edinburg, Texas, USA.

ZOOBANK http://zoobank.org/urn:Isid:zoobank.org:pub:1EF9C159-0EE3-403E9DC8-C42908ED3DB0

\section{Abstract}

The pet trade is a significant source of introductions of non-indigenous aquatic species, such as crayfish. To test whether legislation that regulates the ownership of ornamental animals for aquariums had the desired effect of reducing the availability of those pets, classified advertising websites were monitored for sales of crayfish in jurisdictions with and without legislation regulating the ownership of crayfish. Advertisements from Canadian provinces with legislation against owning crayfish were compared to provinces without such legislation. The population adjusted number of advertisements for crayfish, and number of distinct sellers of crayfish, was significantly lower in one of two provinces that prohibited crayfish compared to provinces that permitted crayfish. This mixed outcome suggests that legislation alone does not consistently reduce online trade in crayfish.

\section{KEY WORDS}

Pet trade, aquariums, legislation, non-indigenous crayfish, prohibited species.

\section{INTRODUCTION}

The pet trade is a large but often poorly understood market (Calado et al., 2003; Rhyne et al., 2012). The supply chain consists of the acquisition, distribution, and sale of animals, and is often complex, poorly monitored, and rife with potential problems at every stage (Fig. 1). In extreme cases, the market for aquatic pets for aquariums can be lucrative enough to provoke criminal activities, including illegal collection from natural populations, smuggling, and in extreme cases, murder (Voigt, 2016). A more mundane but common problem is that the pet trade is a major pathway for introductions of unwanted non-indigenous species (Duggan et al., 2006; Keller and Lodge, 2009; Chucholl, 2013), particularly for freshwater aquatic animals (Duggan et al., 2006; Yanai et al., 2017) such as crayfish (Chucholl, 2013; Faulkes, 2015a; Lipták and Vitázková, 2015; Pârvulescu et al., 2017; Weiperth et al., 2017). The pet trade in crayfish is probably a relatively small segment of the ornamental aquarium trade, but the value people place on crayfish as aquarium pets can be substantial. In Thailand, one single crayfish was sold 
as an aquarium pet for one million baht $(\sim \mathrm{US} \$ 27,000)$ (Anonymous, 2007a; 2007b; 2007c). The trade in crayfish for aquarium pets has a disproportionate potential for significant scientific and ecological effects (Faulkes, 2015a). Crayfish are keystone species that act as ecosystem engineers (Creed, 1994; Momot, 1995; Nyström et al., 1996; Usio et al., 2009; Weinländer and Füreder, 2016), so the biological and economic effects of introductions of nonindigenous crayfish species to new locations are often substantial. The economic impacts of crayfish introductions have generally been negative (Twardochleb et al., 2013). Seven crayfish species are listed among the worst one hundred invasive species in Europe (Nentwig et al., 2018): Procambarus clarkii (Girard, 1852), Procambarus virginalis Lyko, 2017 or Procambarus fallax (Hagen, 1870) forma virginalis, Pacifastacus leniusculus (Dana, 1852), Cherax quadricarinatus (von Martens, 1868), Cherax destructor Clark, 1936, Faxonius virilis (Hagen, 1870), and Faxonius limosus Rafinesque, 1817

\section{Pet crayfish supply chain}

\author{
Sustainable collection
}
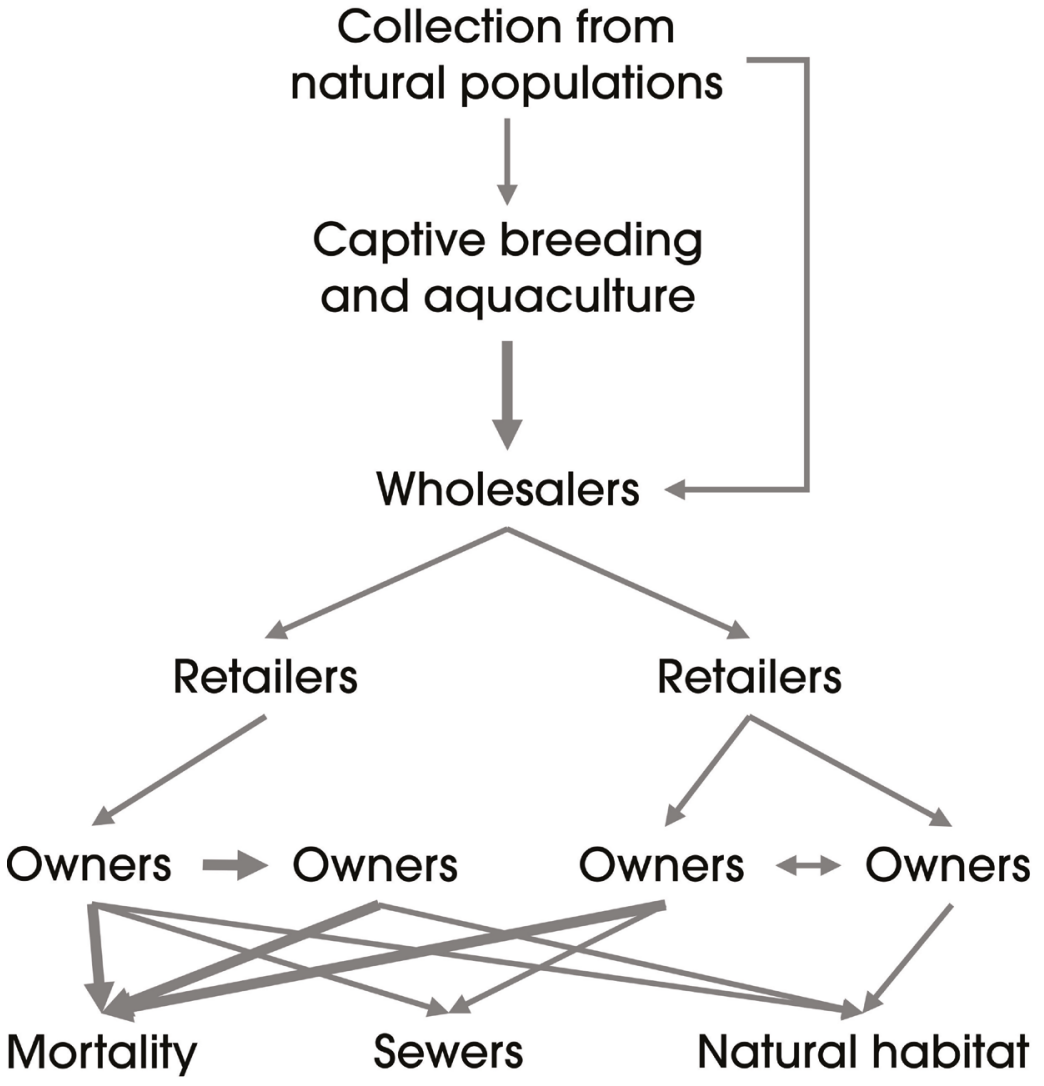

Potential problems

Poor animal care

\begin{abstract}
Poorly tracked import of non-native species
\end{abstract}
Inadequate information to buyers

\title{
Unwanted release \\ Invasion or contamination
}

Figure 1. Supply chain of ornamental species in the pet trade. Any species sold in the aquarium trade is initially taken from wild populations (Ng and Tan 1997; Raghavan et al., 2013), although aquaculture can replace collection from the wild as a supply for the pet trade (Ng and Tan 1997; Voigt, 2016). Most freshwater aquarium fish species are aquacultured (Whittington and Chong, 2007; Maceda-Veiga et al., 2016), although the proportion for crayfish species that are aquacultured is unknown. Breeders and wholesalers may be one and the same entities. These are unlikely, however, to deal directly with the members of the public who buy and own pets. Retailers are the main source of animals for sale to the public, although owners may share or sell pets directly among themselves (Faulkes, 2015b). Aquatic pets often die in captivity, but those that do not may be released alive either into sewer systems (Assis et al., 2014; Patoka et al., 2014; Blanchette, 2016), where probability of survival is low, or into outdoor habitats (Chucholl, 2013; Pârvulescu et al., 2017), where they may become unwanted introduced species. Even when crayfish die in captivity or soon after release, they can still spread diseases post mortem, such as crayfish plague (Oidtmann et al., 2002) if their bodies contact natural ecosystems. 
(the latter two formerly in the genus Orconectes Cope, 1872). All seven species available as pets in at least two countries (Faulkes, 2015a), and the four species in the genera Procambarus Ortmann, 1905 and Cherax Erichson, 1846 are sold in at least six countries (Faulkes, 2015a), and many countries have not been studied. Given this, it is not surprising that the International Association for Astacology recommended countries "stop the importation of living crayfish" (International Association of Astacology, 1988). Several jurisdictions have tried to prevent the sale and release of crayfish using legislation (DiStefano et al., 2009; Faulkes, 2013; Magalhães and Andrade, 2015).

There are several potential methods available to prevent unwanted introductions, but two of the major ones are aimed at the owners at the end of the supply chain (Fig. 1), either by education (Baruch-Mordo et al., 2011; Azevedo-Santos et al., 2015; Seekamp et al., 2016) or regulation (Magalhães and Andrade, 2015). There has been no published research on educational campaigns concerning crayfish in particular regions, although a campaign for aquarium pets in general had minimal effectiveness (Seekamp et al., 2016). Two previous papers examined the effectiveness of legislation on crayfish sales as bait and pets, and both found little evidence they had the desired effects (DiStefano et al., 2009; Magalhães and Andrade, 2015). Magalhães and Andrade (2015) examined banning Louisiana red swamp crayfish ( $P$. clarkii) by comparing availability of crayfish before and after legislation was passed in Brazil. There was a statistically significant decrease in the availability of crayfish in pet stores when measured nationally, but Magalhães and Andrade (2015) concluded Brazilian legislation "had not been effective" (Magalhães and Andrade, 2015). Presumably, Magalhães and Andrade (2015) considered "zero availability of crayfish in pet stores" to be the target for success. But policy outcomes are more nuanced than "success" or "failure." Ideally, trade would be reduced almost to zero, though there may still be rare cases. But a ban on a presumptive invasive species need not reduce availability to zero to have positive impacts. From a public policy perspective, any reduction of availability in retail pet stores reduces the probability of later release of crayfish, or other undesirable effects (Fig. 1). At the other end of the spectrum, regulation might be considered a failure if it had no effect on trade, but this is not the worst possible outcome. Regulation could backfire and increase the illegal trade in species due to perceived rarity (Angulo et al., 2009; Courchamp et al., 2006).

Whether the Brazilian ban on crayfish was responsible for the reduction in availability (Magalhães and Andrade, 2015) is open to interpretation. A potential confound is that there is no way to identify whether pet availability would have changed in the absence of legislation. The popularity of pet types is often driven by social contagion, i.e., fads and fashion (Herzog et al., 2004; Herzog, 2006; Ghirlanda et al., 2013). For example, there was a significant increase in interest in keeping invertebrates, such as crayfish, as aquarium pets in the 1990s in Europe (Chucholl, 2013 ; 2016). By the mid 2000s, over 100 crayfish species were available in the German aquarium trade (Chucholl, 2013). Interest later declined, as did the number of available crayfish species in the German pet trade (Chucholl and Wendler, 2016). Similarly, where those pets are sourced from changes (Robinson et al., 2015).

An alternate approach to "before and after" comparisons is comparing jurisdictions with and without legislation simultaneously. Monitoring the trade in pets in multiple jurisdictions presents a logistical problem since they normally cover large areas, but monitoring online sales provides a feasible way to achieve this. Examining online sales has proven useful in assessing trade in organisms (Kay and Hoyle, 2001; Magalhães and Jacobi, 2010; Magalhães and SãoPedro, 2012; Humair et al., 2015; Mazza et al., 2015), and the risks posed by pet ownership (Kikillus et al., 2012). Furthermore, people will sometimes disclose illegal activities in online forums (Magalhães and SãoPedro, 2012; Huffer and Chappell, 2014; El Bizri et al., 2015; Shiffman et al., 2017). Further advantages include that examining online sales uses publicly available information, so does not require approval for research with human subjects; it requires less effort in collecting data; the data can be quantitative, rather than broad and loosely defined categories of availability such as "very common" or "rare" (e.g. Chucholl, 2013; Chucholl and Wendler, 2016; Kotovska et al., 2016). This paper compares online sales of crayfish in multiple jurisdictions, with differing legislation regarding crayfish, over two years. Under the hypothesis that 
legislation prohibiting crayfish is effective, the number of advertisements and sellers is predicted to be smaller in all provinces with legislation compared to those without legislation.

\section{Materials And Methods}

The online classified web sites Kijiji (http:// kijiji.com), eBay Classifieds (http://ebayclassifieds. com), and Craigslist (http://craigslist.com) were selected as data sources based on previous research (Faulkes, 2013). These websites function differently, which was considered in selecting jurisdictions to monitor. Kijiji targets Canadian users, while eBay Classifieds targets American users, and both group advertisements by entire provinces or states in many cases. Craigslist advertisements are grouped by cities, and both Canadian and American cities are included in its listings.

I used Kijiji to study four Canadian provinces. The Canadian provinces of Manitoba and Alberta had laws prohibiting crayfish throughout the study period, from the start of 2016 to the end of 2017 (Anonymous, 2018; Manitoba Sustainable Development, 2018). The laws concerning crayfish in both provinces were broadly worded: both prohibited people from possessing crayfish of any species. Thus, there is little room those selling crayfish online to misunderstand the intent of the law, or for accidentally breaking the law (e.g., misidentifying a banned crayfish species as a permitted species).

Ideally, the "control" jurisdictions without laws concerning crayfish should meet three criteria. First, they should be served by the same websites. Second, they should be geographically adjacent. Third, they should have a similar population size. The populations for Canadian provinces were taken from 2016 census data from Statistics Canada (http://www12.statcan. gc.ca/census-recensement/2016/dp-pd/hlt-fst/pd$\mathrm{pl} /$ Table.cfm ? Lang $=$ Eng \& $\mathrm{T}=101 \& \mathrm{~S}=50 \& \mathrm{O}=\mathrm{A})$. The 2016 population of Manitoba was $1,278,365$, and Alberta's was $4,067,175$. The estimated populations for American cities were taken from the 2012-2016 American Community Survey five year estimates from the United States Census Bureau (http://factfinder. census.gov/faces/nav/jsf/pages/index.xhtml).
The Canadian prairie province of Saskatchewan met all three criteria for a control (served by Kijiji; adjacent to both provinces; 2016 population of 1,098,352), and Nova Scotia met two: it was served by Kijiji, and its population was the closest to the other three provinces (2016 population of 923,598 ). Initially, I also monitored the American states of North Dakota and Montana, with the intention of comparing them to the four Canadian provinces above, because they met two of the three criteria to be a control jurisdiction. The American states are adjacent to the Canadian provinces, and have similar demographics, but were served by eBay Classifieds rather than Kijiji. Because Kijiji is a subsidiary of eBay Classifieds, I initially assumed that these two services would be roughly comparable. This assumption was incorrect (Asuten, 2015). On 30 September 2016, the eBay Classifieds website shut down, and attempts to navigate to the URL were directed to a new local classifieds website, Close 5 (https://www.close5.com). Because eBay Classifieds had posted zero advertisements for crayfish in those nine months, Close 5 was not monitored.

On the website Craigslist, advertisements are grouped by city. I monitored Craiglist for advertisements for in each of the four Canadian provinces monitored by Kijiji: Winnipeg, Manitoba; Regina and Saskatoon, Saskatchewan; Halifax, Nova Scotia; Calgary, Edmonton, Fort McMurray, Lethbridge, Medicine Hat, Peace River, and Red Deer, Alberta. I also used Craigslist to monitor Rochester, Minnesota and Green Bay, Wisconsin, both located in states with laws prohibiting crayfish (Wisconsin Natural Resources, 2017; Minnesota Department of Natural Resources, 2018). I selected Fargo, North Dakota, Cedar Rapids, Iowa, and Rockford, Illinois as "control" jurisdictions with no such laws, following the three criteria for "control" listed above. To meet the second criteria of similar population size, the American cities chosen all had populations between 100,000 and 200,000.

From 2 January 2016 to 31 December 2017, the online websites were monitored, initially by visiting and searching each site daily, followed by the creation of automated alerts, using the words "crayfish," "crawfish," and "crawdad." I recorded the date and URL of the advertisement; the description, cost, and number of crayfish; and location of the advertiser. I archived 
advertisements as PDF files and saved each picture in the advertisement that showed any crayfish.

The number of individual advertisements may not reflect the availability of crayfish, because sellers can relist advertisements for the same animals. Sellers vary substantially in how many advertisements they create (Faulkes, 2015b). Unlike auction sites studied previously (e.g., Aquabid) (Faulkes, 2015b), the advertising websites monitored here do not provide user names. To estimate the number of sellers, relisted and duplicate ads were identified examining advertisements for duplicate text, pictures, and geographic locations of advertisers.

Data were not normally distributed, so were analyzed using non-parametric statistics using IBM SSPS Statistics version 25 (IBM, Armonk, NY, USA, 2017).

\section{Results}

Only the Canadian classifieds website Kijiji provided enough data over the course of the study period to analyze ( $n=287$ advertisements). Kijiji advertisements largely originated from major cities (Fig. 2). No advertisements for crayfish were ever posted in eBay Classifieds. No city yielded more than two advertisements on Craigslist over the two years of this study and were not examined further.

Provinces differed significantly in both the number of advertisements per month per million people (Fig. 3A; Kruskal-Wallis = 43.58, n=96, df=3, p <0.01). Provinces also differed significantly in the number of unique sellers per month per million people (Fig. 3B; (Kruskal-Wallis $=42.81, \mathrm{n}=96, \mathrm{df}=3, \mathrm{p}<0.01$ ). Both the number of advertisements and number of sellers in Manitoba (crayfish prohibited) were significantly lower than the other three provinces. Alberta (crayfish prohibited), Saskatchewan (permitted), and Nova Scotia (permitted) did not differ from each other in number of advertisements or sellers.

Species identifications were rarely provided by sellers (9 of 287 advertisements; 3\%). The species that were listed in advertisements were Cambarellus diminutus Hobbs, 1945, Cambarellus patzcuarensis Villalobos, 1943 (orange morph), Cambarellus texanus Albaugh \& Black, 1973, Cherax pulcher Lukhaup, 2015, C. destructor, C. quadricarinatus, Cherax snowden
Lukhaup, Panteleit \& Schrimpf, 2015, Procambarus acutus (Girard, 1852), and P. clarkii. Some species were almost certainly misidentified, however. Some blue crayfish were listed as "Australian" or identified as belonging to the genus Cherax, but pictures provided in the advertisement sometimes showed features that are characteristic of the North American genus Procambarus (e.g., prominent tubercles on the claws; Fig. 4).Judging from common names or descriptions, the blue morph of the Everglades crayfish [Procambarus alleni (Faxon, 1884)] and the marbled crayfish Marmorkrebs ( $P$. virginalis or $P$. fallax $\mathrm{f}$. virginalis) appeared to be the most common species in the Canadian provinces studied. Forty percent (115 of 287) of advertisements described the crayfish as "blue," but not "marbled" or "cloning." Many crayfish species can be blue, but photos provided in advertisements often showed the conspicuous dark spots on either side of the mouth that are characteristic of $P$. alleni (Hendrix and Loftus, 2000). Twenty-four percent (69 of 287) of advertisements described the crayfish for sale as "marbled" or "self cloning." Thus, it is likely that these two species may make up about half of the crayfish available online in these provinces.

The number of crayfish described as being available in a single advertisement ranged from one to "a few hundred." No information about the number of crayfish available could be determined from the advertisement (including counting crayfish in pictures provided by the seller) in $31 \%$ ( 89 of 287 ) of the ads. Of the remaining advertisements, most listed small numbers of crayfish, with $63.6 \%$ ( 126 of 198) of advertisement saying 1 to 4 crayfish were available, consistent with advertisements being placed by individual owners rather than business.

\section{DIsCussion}

Legislation prohibiting the ownership of crayfish does not consistently achieve the predicted effect of reducing ownership and availability of crayfish, as measured by online advertisements. One province with legislation prohibiting crayfish (Manitoba) had significantly lower numbers of advertisements and sellers of crayfish online, but another province with similar prohibitions (Alberta) did not. Successful policy change requires public interest (Phillis et al., 2013), but just putting policy in place does not automatically equal desired outcomes. Successful 
A

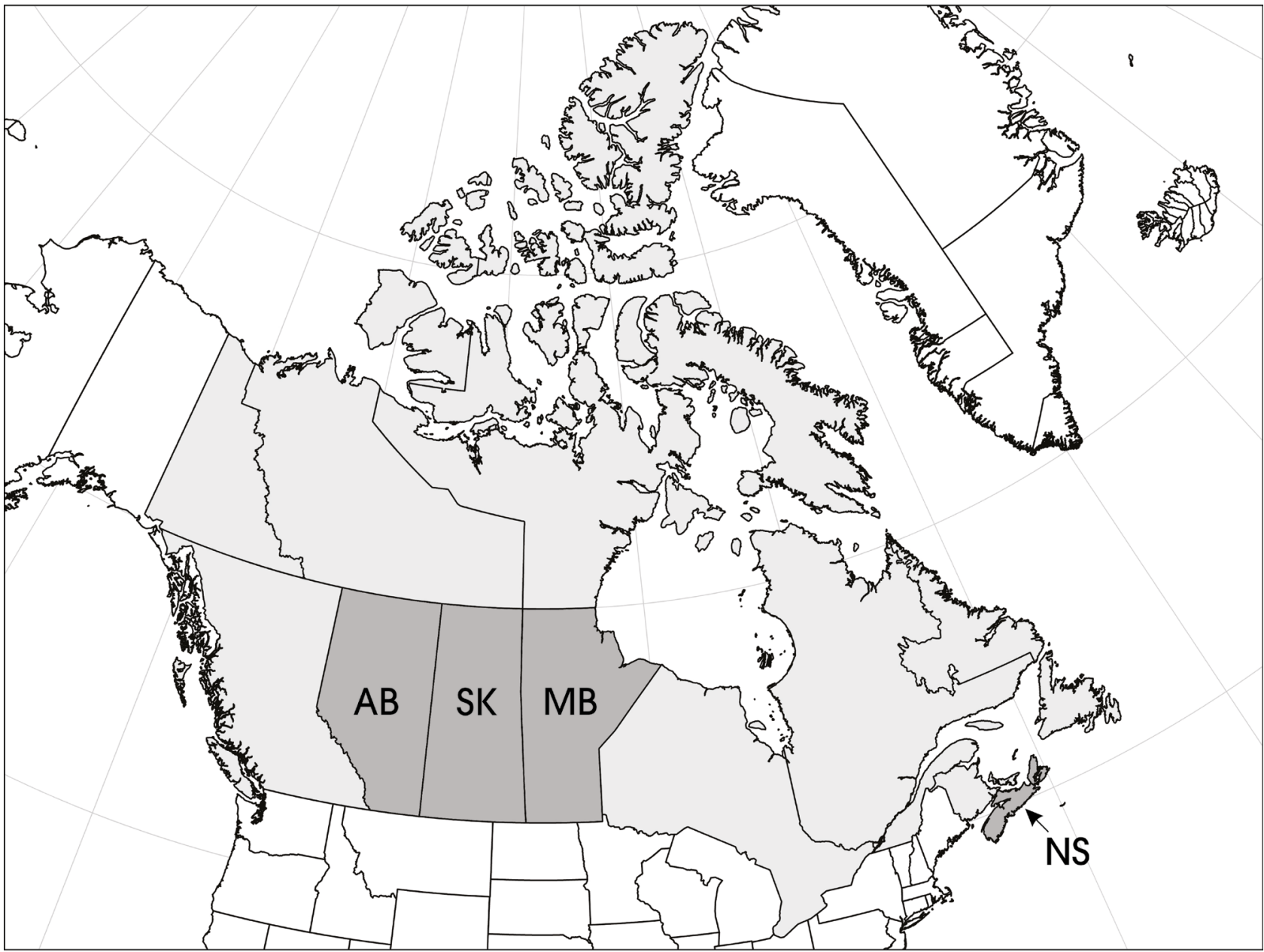

B

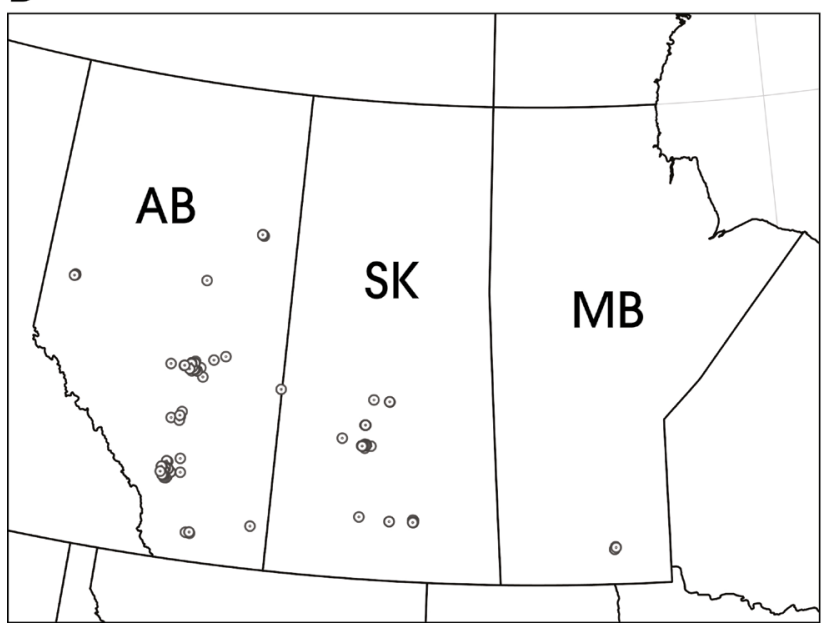

C

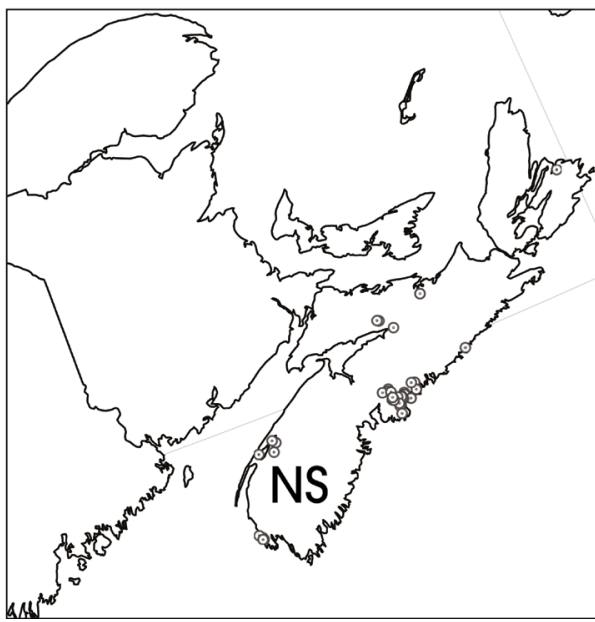

Figure 2. A, Map of Canada (light gray) with focal provinces in this study shown in dark gray. B, Map of Canadian prairie provinces of Alberta (AB), Saskatchewan (SK), and Manitoba (MB), with dots showing locations of sellers placing advertisements for crayfish on Kijiji. Most dots concentrate around cities such as Calgary and Edmonton (AB), Regina and Saskatoon (SK), and Winnipeg (MB). C, Canadian Atlantic province of Nova Scotia (NS), with dots showing locations of sellers placing advertisements for crayfish on Kijiji. Most dots are near the city of Halifax. 


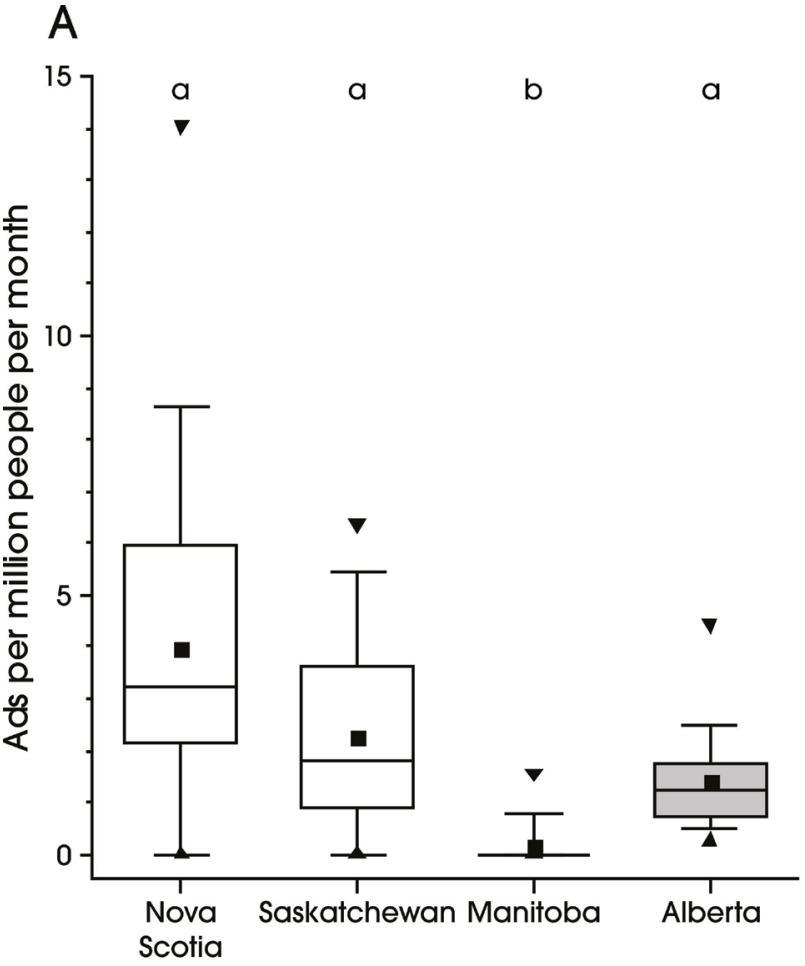

Permitted

Prohibited

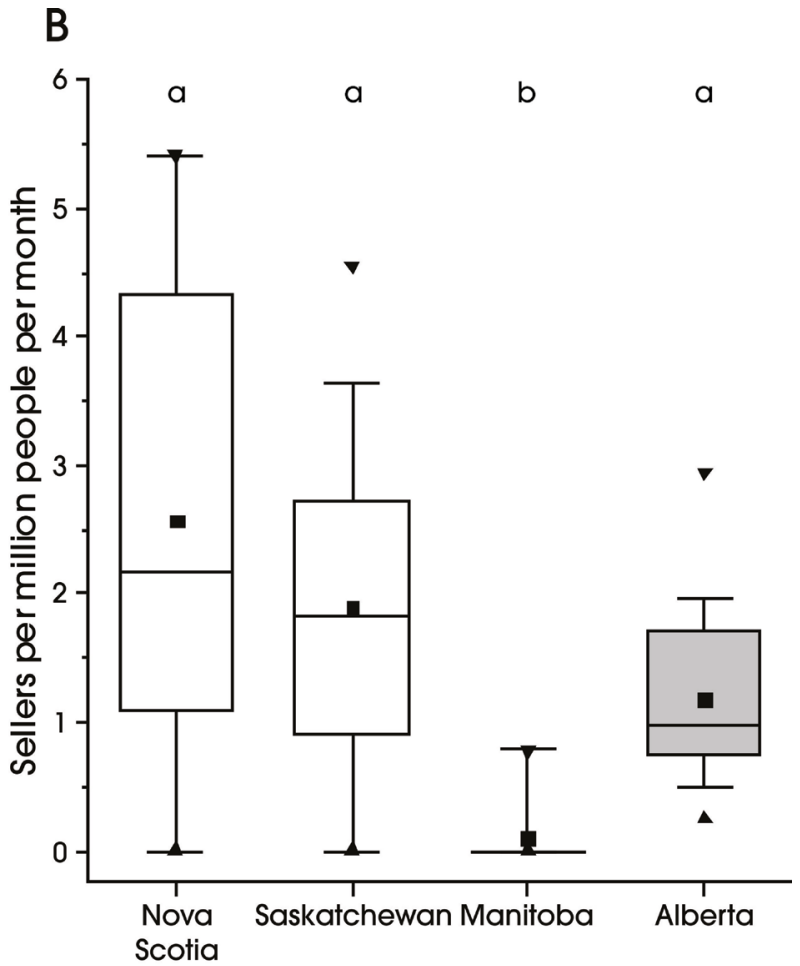

Permitted
Prohibited

Figure 3. Online sales of crayfish in selected Canadian provinces. A, number of individual advertisements per month per million people in the population. B, number of individual sellers placing ads per month per million people in the population. In both, provinces that do not differ statistically share a lowercase letter above the box. Square = mean; horizontal line $=$ median; box $=50 \%$ of data; whiskers $=95 \%$ of data; triangles $=$ minimum and maximum.

policy implementation not only requires public agreement with the goals of the policy (Phillis et al., 2013), but also public education that the policy exists, and visible, consistent enforcement of the policy. In the case of the latter, Canadian federal law prohibits the release of fish (including crayfish) into natural habitats (Government of Canada, 2015), but there has never been a single conviction under that law (Nova Scotia Fisheries and Aquaculture, 2015). A similar situation exists in Brazil: the release of pets is illegal (Oliveira et al., 2014), but there has never been a conviction under that law (Azevedo-Santos et al., 2015). It seems unlikely that Manitoba invests more resources into education and enforcement regarding laws around crayfish than Alberta, and more probable that the differences in availability are due to other currently unknown factors.

Few crayfish were identified to species in ads, and descriptions listed in the advertisement were sometimes wrong (Fig. 4). This suggests that "blacklist" or "whitelist" approaches that attempts to legislate the trade of crayfish on a species by species basis (e.g., only Faxonius rusticus (Girard, 1852) is prohibited in Saskatchewan; Government of Saskatchewan, 1994) will be difficult to enforce. Legislation targeting some species but not others is only as good as the ability of stakeholders (e.g., suppliers, owners, or enforcement agents) to identify species. Invertebrates are often misidentified, even by dealers (DiStefano et al., 2009; Baeza and Behringer, 2017). It seems unlikely that there are enough skilled taxonomists to perform the work that would be needed for quality control in the pet trade (Lee, 2000; Hopkins and Freckleton, 2002). Species identification using photographs is difficult for experts and non-experts alike (Austen et al., 2016). Genetic techniques like DNA barcoding could improve identification (Collins et al., 2012), but species often enter the pet trade before being described scientifically (Daub, 2011; Faulkes, 2015a). Consequently, DNA barcodes may not be available for many species.

A challenge in this project was finding the relevant legislation. In a previous project, I identified Saskatchewan having legislation prohibiting crayfish 

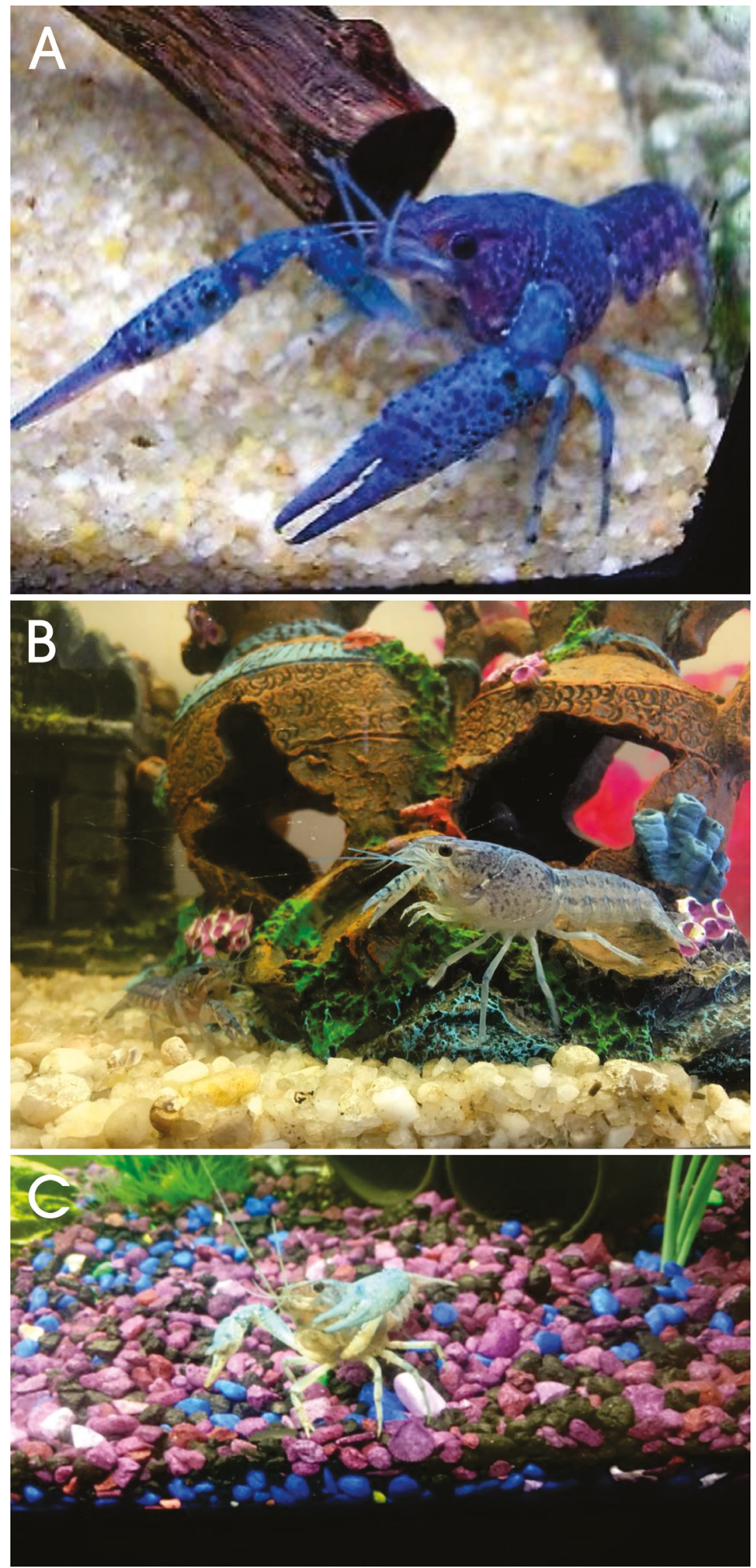

Figure 4. Crayfish that have probably been misidentified by their sellers. A-C, representative pictures of crayfish described as Cherax or "Australian" in online advertisements. All appear to be members of the North American genus Procambarus. 
(Faulkes, 2013), and found no relevant legislation concerning crayfish in Alberta. In this paper, the legislative status of crayfish in those two provinces is reversed. Most crayfish (except F. rusticus; previously $O$. rusticus) are permitted in Saskatchewan (Government of Saskatchewan, 1994), but not in Alberta (Anonymous, 2018). Saskatchewan made legislative changes regarding crayfish in 2011 (Government of Saskatchewan, 2011), during the data collection period for (Faulkes, 2013). The Alberta legislation had been missed in prior searches of provincial government websites. If a motivated researcher with expertise in the field has difficulty finding correct and current information about legislation, pet owners, who may be somewhat less motivated and are not experts in environment policy, seem to have little chance to know whether they are breaking any laws by owning crayfish in their aquariums.

This project again shows the importance of initial website selection when monitoring online resources (Faulkes, 2017). Websites that have nominally similar function - placing local advertisements - yield very different datasets. Here, Kijiii provided a large dataset, while Craigslist provided one so small as to be unusable. Websites further distinguish themselves into smaller marketing niches. Aquabid, used in a previous study (Faulkes, 2015b), is a dedicated website for aquarium hobbyists, and probably attracts users with different interests and more expertise, than a generic classified advertising site like Kijiji. This may be reflected in differences between Kijiji and Aquabid. For example, this study found that marbled crayfish, $P$. virginalis or P. fallax forma virginalis, were listed in a smaller proportion of advertisements than previous research ( $25 \%$ on Kijiji compared to $48.5 \%$ on Aquabid) (Faulkes, 2015b). I hypothesize that Kijiji users were more likely to buy their crayfish from retail stores, where "blue" crayfish like P. alleni are readily available, and that Aquabid users were more likely to buy their crayfish from other pet owners, which was the main pathway for the spread of marbled crayfish (Faulkes, 2010). Kijiji often provided more precise geographic information about the location of sellers, which Aquabid provided more data about the number of crayfish offered, what percentage were bought, and at what price.
Although it has been decades since the Lausanne Resolution called for banning most importation of crayfish (International Association of Astacology, 1988), it is apparent that most governments have not heeded the recommendation. Legislation varies substantially from jurisdiction to jurisdiction, even geographically adjacent ones (this study). Furthermore, the resolution could not have anticipated the rise of Internet commerce in the 1990s, with the resulting diffusion of trade between many individuals rather than a few identifiable companies. It may be time to revise the sort of policy recommendations embodied by the Lausanne Resolution away from simple prohibition to a multi-pronged approach. Possibilities include encouraging trade of crayfish posing the lowest risk of introductions to "outcompete" higher risk species in popularity; more enforcement; and much more education of owners of responsible ownership and disposal of unwanted or dead aquarium pets.

\section{RefERENCES}

Angulo, E.; Deves, A.-L.; Saint Jalmes, M. and Courchamp, F. 2009. Fatal attraction: rare species in the spotlight. Proceedings of the Royal Society B: Biological Sciences, 276: 1331-1337.

Anonymous. 2017a. Crayfish with rare colours sets B1m record. In Bangkok Post. (The Post Publishing Public Company Limited, Bangkok, Thailand). Available at http://www.bangkokpost. com/news/general/1190236/crayfish-with-rare-colourssets-b1m-record. Accessed on 27 April 2018.

Anonymous. 2017b. Distinctive species of ghost crayfish fetches one million baht price. Available at http://englishnews. thaipbs.or.th/distinctive-species-ghost-crayfish-fetches-onemillion-baht-price/. Accessed on 6 February 2017.

Anonymous. 2017c. Man sells cow-patterned crayfish for 1 million baht. Available at http:/ /bangkok.coconuts.co/2017/02/01/ man-sells-cow-patterned-crayfish-1-million-baht. Accessed on 6 February 2017.

Anonymous. 2018. 2018 Alberta Guide to Sportfishing Regulations. Sports Scene Publications Inc.

Assis, D.A.S.; Cavalcante, S.S. and Brito, M.F.G. 2014. Aquarium trade as a potential disseminator of non-native invertebrates in Northeastern Brazil. Neotropical Biology and Conservation, 9: 115-119.

Asuten, I. 2015. Kijiji, a flop in the U.S., rules online classifieds in Canada. In The New York Times. Available at http:/ / www. nytimes.com/2015/05/18/technology/kijiji-a-flop-in-theus-rules-online-classifieds-in-canada.html. Accessed on 27 April 2018.

Austen, G.E.; Bindemann, M.; Griffiths, R.A. and Roberts, D.L. 2016. Species identification by experts and non-experts: comparing images from field guides. Scientific Reports, 6: 33634. 
Azevedo-Santos, V.M.; Pelicice, F.M.; Lima-Junior, D.P.; Magalhães, A.L.B.; Orsi, M.L.; Vitule, J.R.S. and Agostinho, A.A. 2015. How to avoid fish introductions in Brazil: education and information as alternatives. Natureza \& Conservação, 13: 123-132.

Baeza, J.A. and Behringer, D.C. 2017. Integrative taxonomy of the ornamental 'peppermint' shrimp public market and population genetics of Lysmata boggessi, the most heavily traded species worldwide. PeerJ, 5: e3786.

Baruch-Mordo, S.; Breck, S.W.; Wilson, K.R. \& Broderick, J. 2011. The carrot or the stick? Evaluation of education and enforcement as management tools for human-wildlife conflicts. PLoS ONE, 6: e15681.

Blanchette, A. 2016. Officials warn: Don't flush your goldfish. In Star Tribune. (Star Tribune Company, Minnsota). Available at http://www.startribune.com/officials-warn-don-t-flushyour-goldfish/365792231/. Accessed on 27 April 2018.

Calado, R.; Lin, J.; Rhyne, A.L.; Araújo, R. and Narciso, L. 2003. Marine ornamental decapods - popular, pricey, and poorly studied. Journal of Crustacean Biology, 23: 963-973.

Chucholl, C. 2013. Invaders for sale: trade and determinants of introduction of ornamental freshwater crayfish. Biological Invasions, 15: 125-141.

Chucholl, C. 2016. Marbled crayfish gaining ground in Europe: the role of the pet trade as invasion pathway. p. 83-114. In: T. Kawai; Z. Faulkes and G. Scholtz (eds), Freshwater Crayfish: A Global Overview. Boca Raton, CRC Press.

Chucholl, C. and Wendler, F. 2016. Positive selection of beautiful invaders: long-term persistence and bio-invasion risk of freshwater crayfish in the pet trade. Biological Invasions, 19: 197-208.

Collins, R.A.; Armstrong, K.F.; Meier, R.; Yi, Y.; Brown, S.D.J.; Cruickshank, R.H.; Keeling, S. and Johnston, C. 2012. Barcoding and border biosecurity: identifying cyprinid fishes in the aquarium trade. PLoS ONE, 7: e28381.

Courchamp, F.; Angulo, E.; Rivalan, P.; Hall, R.J.; Signoret, L.; Bull, L. and Meinard, Y. 2006. Rarity value and species extinction: The anthropogenic Allee effect. PLoS Biology, 4: e415.

Creed, R.P., Jr. 1994. Direct and indirect effects of crayfish grazing in a stream community. Ecology, 75: 2091-2103.

Daub, E. 2011. Understanding L-Numbers in catfish identification. In That Fish Blog, vol. 2018. (thatpetplace.com). Available at http://blogs.thatpetplace.com/thatfishblog/2011/06/07/ understanding-l-numbers-in-catfish-identification/.Accessed on 27 April 2018.

DiStefano, R.J.; Litvan, M.E. and Horner, P.T. 2009. The bait industry as a potential vector for alien crayfish introductions: problem recognition by fisheries agencies and a Missouri evaluation. Fisheries, 34: 586-597.

Duggan, I.; Rixon, C. and MacIsaac, H. 2006. Popularity and propagule pressure: determinants of introduction and establishment of aquarium fish. Biological Invasions, 8: 377382.

El Bizri, H.R.; Morcatty, T.Q.; Lima, J.J.S. and Valsecchi, J. 2015. The thrill of the chase: uncovering illegal sport hunting in Brazil through YouTube ${ }^{\mathrm{TM}}$ posts. Ecology and Society, 20: 30.

Faulkes, Z. 2010. The spread of the parthenogenetic marbled crayfish, Marmorkrebs (Procambarus sp.), in the North American pet trade. Aquatic Invasions, 5: 447-450.
Faulkes, Z. 2013. How much is that crayfish in the window? Online monitoring of Marmorkrebs, Procambarus fallax $\mathrm{f}$. virginalis (Hagen, 1870) in the North American pet trade. Freshwater Crayfish, 19: 39-44.

Faulkes, Z. 2015a. The global trade in crayfish as pets. Crustacean Research, 44: 75-92.

Faulkes, Z. 2015b. Marmorkrebs (Procambarus fallax f. virginalis) are the most popular crayfish in the North American pet trade. Knowledge and Management of Aquatic Ecosystems, 416: 20.

Faulkes, Z. 2017. Slipping past the barricades: the illegal trade of pet crayfish in Ireland. Biology and Environment: Proceedings of the Royal Irish Academy, 117: 15-23.

Ghirlanda, S.; Acerbi, A.; Herzog, H. \& Serpell, J.A. 2013. Fashion vs. function in cultural evolution: The case of dog breed popularity. PLoS ONE, 8: e74770.

Government of Canada. 2015. Fishery (General) Regulations SOR/93-53. Available at http:/ /laws-lois.justice.gc.ca/eng/ regulations/SOR-93-53/FullText.html. Accessed on 27 April 2018.

Government of Saskatchewan. 1994. The Fisheries Regulations. Available at http://publications.gov.sk.ca/details. $\mathrm{cfm} ? \mathrm{p}=1116$. Accessed on 27 April 2018.

Government of Saskatchewan. 2011. Revised regulations of Saskatchewan, Saskatchewan Regulations 59/2011 The Fisheries Act (Saskatchewan), 1994. The Saskatchewan Gazette, Part II 11: 955-956. Available at http://www.publications. gov.sk.ca/details.cfm?p=32857. Accessed on 27 April 2018.

Hendrix, A.N. and Loftus, W.F. 2000. Distribution and relative abundance of the crayfishes Procambarus alleni (Faxon) and P. fallax (Hagen) in southern Florida. Wetlands, 20: 194-199.

Herzog, H. 2006. Forty-two thousand and one dalmatians: Fads, social contagion, and dog breed popularity. Society \& Animals, 14: 383-397.

Herzog, H.A.; Bentley, R.A. and Hahn, M.W. 2004. Random drift and large shifts in popularity of dog breeds. Proceedings of the Royal Society of London. Series B: Biological Sciences, 271: S353-S356.

Hopkins, G.W. and Freckleton, R.P. 2002. Declines in the numbers of amateur and professional taxonomists: implications for conservation. Animal Conservation, 5: 245-249.

Huffer, D. and Chappell, D. 2014. The mainly nameless and faceless dead: an exploratory study of the illicit traffic in archaeological and ethnographic human remains. Crime, Law and Social Change, 62: 131-153.

Humair, F.; Humair, L.; Kuhn, F. \& Kueffer, C. 2015. E-commerce trade in invasive plants. Conservation Biology, 29: 1658-1665.

International Association of Astacology. 1988. Lausanne Resolution. Freshwater Crayfish, 7: XI.

Kay, S.H. and Hoyle, S.T. 2001. Mail order, the Internet, and invasive aquatic weeds. Journal of Aquatic Plant Management, 39: 88-91.

Keller, R.P. and Lodge, D.M. 2009. Species invasions from commerce in live aquatic organisms: problems and possible solutions. BioScience, 57: 428-436.

Kikillus, K.H.; Hare, K. and Hartley, S. 2012. Online trading tools as a method of estimating propagule pressure via the pet-release pathway. Biological Invasions, 14: 2657-2664.

Kotovska, G.; Khrystenko, D.; Patoka, J. and Kouba, A. 2016. East European crayfish stocks at risk: arrival of non-indigenous 
crayfish species. Knowledge and Management of Aquatic Ecosystems, 417: 37.

Lee, M.S.Y. 2000. A worrying systematic decline. Trends in Ecology \& Evolution, 15: 346.

Lipták, B. and Vitázková, B. 2015. Beautiful, but also potentially invasive. Ekológia (Bratislava), 34: 155-162.

Maceda-Veiga, A.; Domínguez-Domínguez, O.; Escribano-Alacid, J. and Lyons, J. 2016. The aquarium hobby: can sinners become saints in freshwater fish conservation? Fish and Fisheries, 17: 860-874.

Magalhães, A.L.B. and Andrade, R.F. 2015. Has the import ban on non-native red swamp crayfish (Crustacea: Cambaridae) been effective in Brazil? Neotropical Biology and Conservation, 10: 48-52.

Magalhães, A.L.B. and Jacobi, C.M. 2010. E-commerce of freshwater aquarium fishes: potential disseminator of exotic species in Brazil. Acta Scientiarum. Biological Sciences, 32: 243-248.

Magalhães, A.L.B. and São-Pedro, V.A. 2012. Illegal trade on non-native amphibians and reptiles in southeast Brazil: the status of e-commerce. Phyllomedusa-Journal of Herpetology, 11: $155-160$.

Manitoba Sustainable Development, F.B. 2018. The Rusty Crayfish (Orconectes rusticus). Available at http://www.gov.mb.ca/sd/ waterstewardship/stopais/rusty_crayfish.html. Accessed on 24 April 2018.

Mazza, G.; Aquiloni, L.; Francesco Inghilesi, A.; Giuliani, C.; Lazzaro, L.; Ferretti, G.; Lastrucci, L.; Foggi, B. \& Tricarico, E. 2015. Aliens just a click away: the online aquarium trade in Italy. Management of Biological Invasions, 6: 253-261.

Minnesota Department of Natural Resources. 2018. Minnesota invasive species laws. Available at https://www.dnr.state. mn.us/invasives/laws.html. Accessed on 27 April 2018.

Momot, W.T. 1995. Redefining the role of crayfish in aquatic ecosystems. Reviews in Fisheries Science, 3: 33-63.

Nentwig, W.; Bacher, S.; Kumschick, S.; Pyšek, P. and Vilà, M. 2018. More than "100 worst" alien species in Europe. Biological Invasions, 20: 1611-1621.

Ng, P.K.L. and Tan, H.H. 1997. Freshwater fishes of Southeast Asia: potential for the aquarium fish trade and conservation issues. Aquarium Sciences and Conservation, 1: 79-90.

Nova Scotia Fisheries and Aquaculture. 2015. Live fish possession regulations. Available at https://novascotia.ca/ fish/sportfishing/resource-management/ais/fcra-qanda. pdf. Accessed on 27 April 2018.

Nyström, P.; Brönmark, C. and Granéli, W. 1996. Patterns in benthic food webs: A role for omnivorous crayfish? Freshwater Biology, 36: 631-646.

Oidtmann, B.; Heitz, E.; Rogers, D. and Hoffmann, R.W. 2002. Transmission of crayfish plague. Diseases of Aquatic Organisms, 52: 259-167.

Oliveira, T.D.; Reis, A.C.; Guedes, C.O.; Sales, M.L.; Braga, E.P.R.; Ratton, T.F.; Maia, B.P. and Magalhães, A.L.B. 2014. Establishment of non-native guppy Poecilia reticulata (Peters, 1859) (Cyprinodontiformes: Poeciliidae) in an Municipal Park located in Minas Gerais State, Brazil. Pan-American Journal of Aquatic Sciences, 9: 21-30.

Pârvulescu, L.; Togor, A.; Lele, S.-F.; Scheu, S.; Șinca, D. and Panteleit, J. 2017. First established population of marbled crayfish Procambarus fallax (Hagen, 1870) f. virginalis (Decapoda, Cambaridae) in Romania. BioInvasions Records, 6: 357-362.

Patoka, J.; Petrtýl, M. and Kalous, L. 2014. Garden ponds as potential introduction pathway of ornamental crayfish. Knowledge and Management of Aquatic Ecosystems, 414: 13.

Phillis, C.C.; O’Regan, S.M.; Green, S.J.; Bruce, J.E.B.; Anderson, S.C.; Linton, J.N.; Earth2Ocean Research Derby and Favaro, B. 2013. Multiple pathways to conservation success. Conservation Letters, 6: 98-106.

Raghavan, R.; Dahanukar, N.; Tlusty, M.F.; Rhyne, A.L.; Krishna Kumar, K.; Molur, S. and Rosser, A.M. 2013. Uncovering an obscure trade: threatened freshwater fishes and the aquarium pet markets. Biological Conservation, 164: 158-169.

Rhyne, A.L.; Tlusty, M.F.; Schofield, P.J.; Kaufman, L.; Morris, J.A., Jr. and Bruckner, A.W. 2012. Revealing the appetite of the marine aquarium fish trade: the volume and biodiversity of fish imported into the United States. PLoS ONE, 7: e35808.

Robinson, J.E.; Griffiths, R.A.; St. John, F.A.V. and Roberts, D.L. 2015. Dynamics of the global trade in live reptiles: Shifting trends in production and consequences for sustainability. Biological Conservation, 184: 42-50.

Seekamp, E.; Mayer, J.E.; Charlebois, P. and Hitzroth, G. 2016. Effects of outreach on the prevention of aquatic invasive species spread among organism-in-trade hobbyists. Environmental Management, 58: 797-809.

Shiffman, D.S.; Macdonald, C.; Ganz, H.Y. and Hammerschlag, N. 2017. Fishing practices and representations of shark conservation issues among users of a land-based shark angling online forum. Fisheries Research, 196: 13-26.

Twardochleb, L.A.; Olden, J.D. and Larson, E.R. 2013. A global meta-analysis of the ecological impacts of nonnative crayfish. Freshwater Science, 32: 1367-1382.

Usio, N.; Kamiyama, R.; Saji, A. \& Takamura, N. 2009. Sizedependent impacts of invasive alien crayfish on a littoral marsh community. Biological Conservation, 142: 1480-1490.

Voigt, E. 2016. The Dragon Behind the Glass: A True Story of Power, Obsession, and the World's Most Coveted Fish. New York, Scribner, 318p.

Weinländer, M. and Füreder, L. 2016. Native and alien crayfish species: do their trophic roles differ? Freshwater Science, 35: 1340-1353.

Weiperth, A.; Gál, B.; Kuř́íková, P.; Bláha, M.; Kouba, A. and Patoka, J. 2017. Cambarellus patzcuarensis in Hungary: The first dwarf crayfish established outside of North America. Biologia, 72: 1529-1532.

Whittington, R.J. and Chong, R. 2007. Global trade in ornamental fish from an Australian perspective: The case for revised import risk analysis and management strategies. Preventive Veterinary Medicine, 81: 92-116.

Wisconsin Natural Resources. 2017. Chapter NR 40 Invasive species identification, classification and control. Available at http://docs.legis.wisconsin.gov/code/admin_code/ nr/001/40/07/6/_1. Accessed on 27 April 2018.

Yanai, Z.; Dayan, T.; Mienis, H.K. and Gasith, A. 2017. The pet and horticultural trades as introduction and dispersal agents of non-indigenous freshwater molluscs Management of Biological Invasions, 8: 523-532. 